\title{
Keterwakilan Perempuan di Ranah Lokal: Studi Kasus di Kecamatan Boawae, Nusa Tenggara Timur dalam Pemilu Legislatif 20I4
}

\author{
Veronika Ina Assan Boro' ${ }^{1}$, Alexander Efraim Tade Kale ${ }^{\mathbf{2}}$ \\ 1,2 Fakultas Ilmu Sosial dan Ilmu Politik, Universitas Katolik Widya Mandira
}

\begin{abstract}
Abstrak:
Penelitian ini mendiskusikan faktor-faktor yang menghambat keterwakilan caleg perempuan di ranah lokal dalam konteks Pemilu Legislatif 2014 di Kabupaten Nagekeo, Nusa Tenggara Timur. Penelitian ini menggunakan metode deskriptif kualitatif dengan mewawancarai informan yang merupakan kandidat pemilu legislative tahun 2014. Temuan penelitian menunjukkan kendala utama keterwakilan perempuan terletak di politik partai yang lebih memprioritaskan calon legislatif (caleg) laki-laki dibandingkan caleg perempuan. Penentuan nomor urut juga berat sebelah. Caleg perempuan ditempatkan pada nomor "urut sepatu". Hambatan kedua pada faktor sosial ekonomi. Dukungan sumber-sumber keuangan bagi caleg perempuan sangat minim. Ketiga adalah hendala kultural budaya terkait dengan kuatnya budaya patriarki di daerah. Perempuan terikat dengan tradisi belis yang dianggap sebagai warge kelas dua. Keempat terkait hambatan dalam diri perempuan sendiri. Calon anggota legislatif perempuan tidak memanfaatkan kelompok-kelompok organisasi kemasyarakatan untuk mendukung mereka dalam berkompetisi dengan caleg laki-laki.
\end{abstract}

\section{Kata Kunci:}

perempuan; pemilu; caleg perempuan; hambatan keterwakilan perempuan

\section{Pendahuluan}

Diskursus mengenai demokrasi sebagai suatu sistem politik telah meniscayakan sebuah semangat persamaan dan kebersamaan demi pencapaian kebaikan bersama (Bonum Comunnae). ${ }^{1}$ Konteks hidup bersama tersebut termanifestasikan dalam suatu kehidupan bernegara dan bermasyarakat. Dibutuhkan bentuk partisipasi sebagai wujud dari kesetaraan dalam proses politik tersebut. Oleh karena itu, partisipasi politik merupakan aspek penting dalam negara demokrasi dan menjadi penanda adanya modernisasi politik.

Implikasi partisipasi politik demikian terwujud dalam keikutsertaan masyarakat dalam pelaksanaan pemilu legislatif merupakan kegiatan warga negara yang bertujuan

Korespodensi:

Fakultas IImu Sosial dan Ilmu Politik, Universitas Katolik Widya Mandira (UNWIRA), J Jl. A. Yani No.66, Merdeka, Kec. Kota Lama, Kota Kupang, Nusa Tenggara Tim.

Email: veronikaboro@yahoo.co.id. 
untuk mempengaruhi pengambilan keputusan politik. Dalam suatu sistem politik demokratis para pemimpin dipilih langsung oleh rakyat guna meneruskan aspirasi rakyat (Dahlerup, 2002: 33; Samego, 2017: 25). Makna pemilu yang paling penting bagi suatu kehidupan yang demokratis adalah sebagai institusi untuk melakukan perubahan kebijakan yang dilakukan melalui pembentukan regulasi, norma, dan etika, sehingga sirkulasi elit politik kekuasaan dapat dilakukan secara damai dan beradab untuk menempatkan wakil rakyat di parlemen baik laki-laki maupun perempuan.

Indonesia sebagai negara merdeka dan berdaulat telah berkomitmen secara tegas memberi pengakuan yang sama bagi setiap warganya, baik itu perempuan maupun lakilaki sama haknya dalam kehidupan berbangsa dan bernegara tanpa kecuali. Hak-hak politik perempuan ditetapkan melalui instrumen hukum maupun dengan meratifikasi berbagai konvensi yang menjamin hak-hak politik tersebut. Adapun hak itu berupa hakhak politik, bahwa setiap orang berhak atas kebebasan berpikir, memiliki dan menyatakan pendapatnya, berserikat dan berkumpul, berpartisipasi dalam pemerintahan, termasuk hak untuk mengambil bagian dalam pemerintahan (Utami, 2001).

Keterwakilan perempuan di lembaga-lembaga negara seperti halnya parlemen merupakan tuntutan yang harus dilakukan untuk membangun sistem yang benar-benar demokratis (Sastriyani, 2009: 201). ${ }^{2}$ Tuntutan kesetaraan gender dalam bidang politik yang disuarakan oleh gerakan-gerakan feminis di Indonesia pada akhirnya membuahkan hasil. Hal ini terbukti dengan dikelurkannya kebijakan affirmatif action, yaitu memberi kuota $30 \%$ bagi perempuan dalam persaingan politik di Indonesia yang termaktub dalam Undang-Undang Pemilu No. 12 Pasal 65 Tahun 2003.

Kebijakan kuota didasari pertimbangan bahwa keterlibatan perempuan dalam politik dianggap penting karena perempuan memiliki kebutuhan-kebutuhan khusus yang hanya dapat dipahami dengan baik oleh perempuan sendiri. Kebutuhan-kebutuhan tersebut antara lain adalah kesehatan reproduksi, masalah kesejahteraan keluarga, masalah kesehatan dan pendidikan anak, kebutuhan manusia lanjut usia dan isu-isu kekerasan seksual (Lovenduski, 2008: 38). Selain itu, keikutsertaan perempuan sebagai pengambil keputusan politik juga dapat mencegah terjadinya diskriminasi terhadap perempuan yang selama ini terjadi dalam masyarakat (Fatmariza, 2005).

Namun demikian, dalam praktiknya keterwakilan perempuan di parlemen terbilang masih rendah, walaupun kebijakan kuota sudah ditetapkan (Dahlerup, 2002). Rendahnya keterwakilan perempuan tersebut tentu tidak bisa dilepaskan dari banyak faktor, antara lain adalah lingkungan sosial masyarakat yang masih terikat oleh budaya patriarki, pemahaman tentang makna politik yang dianggap kotor dan keras (Mulia \& Farida, 2005; 16). Masalah perempuan dan politik di Indonesia terhimpun sedikitnya dalam empat isu: keterwakilan perempuan yang sangat rendah di ruang publik; komitmen partai politik yang belum sensitif gender sehingga kurang memberikan akses memadai 
bagi kepentingan perempuan; kendala nilai-nilai budaya dan interpretasi ajaran agama yang bias gender dan bias nilai-nilai patriarki; dan minat, hasrat, animo, para perempuan untuk terjun dalam kancah politik rendah; tapi untuk yang terakhir ini perlu dilakukan pengkajian lebih mendalam (Hasyim, 2010: 124).

Berbagai polemik yang mempengaruhi rendahnya partisipasi perempuan di ranah publik adalah bentuk pemahaman masyarakat umum (mainstream) yang menganggap bahwa perempuan yang aktif dan luas bergaul dengan siapapun seringkali dimaknai secara peyoratif (merendahkan). Indikator partisipasi politik perempuan dapat dilihat dalam tiga aspek, yaitu akses, kontrol, dan suara perempuan dalam proses pembuatan kebijakan (policy making process). Realitas menunjukkan bahwa dalam tiga aspek di atas keterlibatan perempuan Indonesia sangat kurang. Hal ini dapat dilihat bahwa hingga saat ini keterwakilan perempuan dalam arena politik sangat minim (Naqiyah, 2005: 78).

Peran perempuan yang belum signifikan dalam pentas politik serta struktur sosial yang belum mendukung perempuan, menjadi faktor utama mengapa perempuan harus menjadi prioritas pemilih yang mendapatkan pendidikan politik (Fakih, 2008: 45). Hal ini untuk menumbuhkan kesadaran politik dan independensi perempuan dalam memilih, perempuan harus memiliki visi misi baru dalam menentukan kandidat yang dipilihnya. Berdasarkan fenomena-fenomena yang terjadi pada Pemilu Legislatif 2014, kemudian timbul pertanyaan bagaimanakah keputusan memilih diambil oleh pelaku pemilih? Memilih menjadi suatu aktifitas yang merupakan proses menentukan sesuatu yang dianggap cocok dan sesuai dengan keinginan seseorang atau kelompok, baik yang bersifat eksklusif maupun yang inklusif.

Fenomena inkonsistensi pemilih dalam menentukan pilihannya merupakan isu penting dalam pemilihan legislatif 2014 di Kabupaten Nagekeo. Legitimasi keterwakilan perempuan sebagai manisfestasi kesetaraan gender dinilai sia-sia. Dalam Pemilihan Umum Legislatif yang digelar pada tahun 2014, ternyata perilaku politik para caleg dan pemilih semakin cenderung bertransaksi secara politik sehingga melahirkan perilaku pragmatis para pemilih, terutama pemilih kalangan bawah. Karakter Perilaku politik ini, berkaitan dengan semakin tingginya daya tawar pemilih untuk memberikan suara kepada salah satu caleg dengan latar belakang parpol.

Hasil Pemilu Legislatif 2014 di Kabupaten Nagekeo menunjukkan bahwa perempuan Nagekeo tidak memiliki satupun keterwakilan anggota dewan perempuan di DPRD Kabupaten Nagekeo. Padahal jumlah pemilih perempuan lebih banyak daripada jumlah pemilih laki-laki. Data hasil Pemilu 2014, berdasarkan data di KPUD Nagekeo, jumlah pemilih terdaftar di Nagekeo terdiri dari 41.321 pemilih laki-laki dan 45.996 pemilih perempuan.

Pada Pemilu Legislatif 2014, di Kabupaten Nagekeo terdapat 338 TPS yang terbagi dalam 3 daerah pemilihan. Dapil Nagekeo 1 yang tediri dari Kecamatan Aesesa 
dengan jumlah pemilih laki-laki 11.853 orang dan pemilih perempuan 12.628 orang, Kecamatan Aesesa Selatan dengan jumlah pemilih laki-laki 1.917 orang dan pemilih perempuan 2.186 orang serta Kecamatan Wolowae dengan jumlah pemilih laki-laki 1.555 orang dan pemilih perempuan 1.664 orang. Dapil Nagekeo 2 yang terdiri dari Kecamatan Nangaroro dengan jumlah pemilih laki-laki 5.604 orang dan pemilih perempuan 6.691 orang, Kecamatan Keo Tengah dengan jumlah pemilih laki-laki 4.184 dan pemilih perempuan 5.016 orang, serta Kecamatan Mauponggo dengan jumlah pemilih laki-laki 6.377 dan pemilih perempuan 6.997 orang. Dapil Nagekeo 3 yang terdiri dari Kecamatan Boawae, dengan jumlah pemilih laki-laki 9.450 orang dan pemilih perempuan 10.225 orang. ${ }^{3}$

Dalam penelitian kali ini, penulis bermaksud memotret persoalan keterwakilan perempuan tersebut dengan melihat salah satu dapil, yaitu Dapil III (Kecamatan Boawae). Sebagaimana data di atas, jumlah pemilih perempuan di Dapil 3 juga lebih banyak perempuan tetapi tidak satupun caleg perempuan yang berhasil terpilih sebagai anggota DPRD. Padahal, nama-nama caleg perempuan juga menghiasi daftar caleg tiap partai politik. Tabel berikut meringkat jumlah caleg laki-laki dan perempuan di tiap partai di Kabupate Nagekeo pada Pileg 2014.

Tabel 1. Jumlah Caleg Pemilu 2014 di Kabupaten Nagekeo berdasarkan jenis kelamin

\begin{tabular}{l|lllllllll}
\multirow{2}{*}{ NO } & NAMA PARPOL & \multicolumn{3}{c}{ DAPIL I } & \multicolumn{2}{c}{ DAPIL II } & \multicolumn{2}{c}{ DAPIL III } & TOTAL \\
\cline { 2 - 10 } & L & P & L & P & L & P & L & P \\
1. & NASDEM & 6 & 3 & 7 & 3 & 4 & 2 & 17 & 8 \\
2. & PKB & 7 & 2 & 7 & 3 & 4 & 2 & 18 & 7 \\
3. & PKS & 6 & 2 & 7 & 3 & 3 & 3 & 16 & 8 \\
4. & PDIP & 6 & 3 & 7 & 3 & 4 & 2 & 17 & 8 \\
5. & GOLKAR & 6 & 3 & 7 & 3 & 4 & 2 & 17 & 8 \\
6. & GERINDRA & 6 & 3 & 7 & 3 & 4 & 2 & 17 & 8 \\
7. & DEMOKRAT & 6 & 3 & 7 & 3 & 3 & 3 & 16 & 9 \\
8. & PAN & 7 & 2 & 7 & 2 & 4 & 2 & 18 & 6 \\
9 & HANURA & 6 & 3 & 7 & 3 & - & - & 13 & 6 \\
10 & PKPI & 6 & 3 & 7 & 3 & 3 & 2 & 16 & 8 \\
JUMLAH & 68 & 30 & 77 & 32 & 37 & 22 & 182 & 84
\end{tabular}

Sumber: Rekapitulasi Suara KPU Nagekeo,2016

Kekalahan perempuan dalam Pileg tahun 2014 di Kabupaten Nagekeo dapat diinterpretasikan bahwa masyarakat masih menganggap potensi perempuan sebagai pemimpin masih tidak layak. Ketidaklayakan perempuan untuk mengambil bagian dalam keseluruhan proses diskursus politik di Nagekeo akan mengafirmasi sebuah teror patriarki yang cenderung dominan di masyarakat Nagekeo. Oleh karena itu peneliti merasa perlu untuk melakukan sebuah kajian yang mendalam tentang fenomena tersebut, terutama dari sisi perilaku pemilih. Atas alasan tersebut peneliti tertarik untuk mengkaji faktor-faktor penghambat terhadap keterwakilan caleg perempuan pada pemilu legislatif 
2014 dengan studi kasus Dapil III (Kecamatan Boawae), Nagekeo, NTT (Samego, 2000: 25).

Beberapa kajian telah mendiskusikan perihal caleg perempuan. Ada yang mengidentifikasi melalui strategi kampanye (Kristoforus Rangga, 2014), strategi branding (Anu, 2015), dan pemosisian perempuan di masyarakat (Ananta, Arifin, \& Suryadinata, 2004). Kegagalan dan keberhasilan caleg juga terkait erat dengan apa yang Rahardjo, (2006: 26) jelaskan sebagai syarat kedemokratisan Pemilu, yang mencakup keterbukaan (penyelenggaraan), ketepatan (sistem pemilu; distrik atau proporsional), dan keefektifan pelaksanaan (Prihatmoko, 2008), terkait pula dengan kedaulatan untuk menentukan wakil rakyat yang memperjuangkan kepentingan rakyat dan bertanggung jawab atas keberhasilannya (Haryanto, 1984). Parpol juga tidak bisa dilepaskan dari persoalan keberhasilan dan kegagalan ini (Budiardjo, 2003: 136; Haboddin \& Rahman, 2013: 103$4)$.

Jika bisa diringkas, maka masalah keterwakilan perempuan di lembaga legislatif terkait faktor eksternal dan faktor internal (Sridanti, 2010). Faktor eksternal merupakan faktor yang berasal dari luar dan berpengaruh terhadap keterwakilan perempuan. Dalam hal ini terdapat 3 (tiga) faktor. Pertama sistem politik, dalam hal ini terkait dengan kebijakan kuota. Sejauhmana sistem kuota ditegakkan akan berpengaruh pada keterwakilan perempuan. Padahal, dari sisi jumlah saja perempuan di legislatif masih sangat terbatas dan tidak representatif (Wijaksana, 2004), mengindikasikan sistem kuota beum kuat. Kedua, faktor partai politik; apakah terbuka atau tidak terhadap caleg perempuan. Ketiga, faktor kultural. Konteks masyarakat Indonesia dikenal sebagai masyarakat yang kuat akan budaya patriarki, yaitu menempatkan perempuan pada posisi yang selalu berada di bawah laki-laki. Gaffar (2000) dan Murniati (2004) mendefinisikan patriarki sebagai suatu sistem yang bercirikan laki-laki (ayah). Dalam sistem ini, laki-laki yang berkuasa untuk menentukan segala sesuatu yang akan dilakukan atau tidak dilakukan. Dalam sistem patriarkhi, perempuan kurang menyadari bahwa dirinya adalah seorang pribadi yang mempunyai hak-hak azasi manusia yang sama. Mereka seringkali kesulitan menghilangkan perasaan malu dan perasaan takut salah. Mereka kurang mampu berpikir jenih dan logis, sehingga sulit dalam mengambil keputusan. Mereka memiliki beban kerja domestik (Ibrahim, 1996). Mereka selalu mempertimbangkan faktor keluarga, atau tradisi turun temurun keluarga yang aktif di organisasi. Dengan budaya patriarki ini, mereka tidak berminat terjun dalam dunia politik termasuk menjadi calon anggota legislatif (Wijaya, 2001).

Faktor internal yaitu faktor dari dalam diri sendiri faktor-faktor dari dalam diri perempuan. Shvedova (1999) mengkategorikan masalah atau kendala yang dihadapi perempuan yang memasuki kehidupan politik di parlemen menjadi 3 jenis, yaitu kendala politik, kendala sosio-ekonomi, dan kendala psikologi atau sosio-kultural. Kendala politik yang utama yang dihadapi perempuan adalah kurangnya dukungan partai, seperti 
terbatasnya dukungan dana bagi kandidat perempuan, terbatasnya akses untuk jaringan politik, dan meratanya standar ganda, kurangnya hubungan dan kerja sama dengan organisasi publik lainnya seperti serikat dagang (buruh) dan kelompok-kelompok perempuan, tiadanya sistem pelatihan dan pendidikan yang berkembang, baik bagi kepemimpinan perempuan pada umumnya maupun bagi orientasi perempuan muda pada kehidupan politik pada khususnya. Adapun kendala-kendala sosio-ekonomi yang mempengaruhi partisipasi perempuan dalam parlemen yaitu kemiskinan dan pengangguran, lemahnya sumber-sumber keuangan yang memadai, dan buta huruf dan terbatasnya akses pendidikan dan pilihan profesi bagi kaum perempuan.

Guna menjawab tujuan yang diuraikan sebelumnya, maka penelitian menggunakan metode penelitian kualitatif. Metode penelitian kualitatif adalah prosedur penelitian untuk mengkaji data baik berupa kata-kata ataupun lisan dari obyek yang diamati (Sugiyono, 2011). Sedangkan sifat penelitian ini adalah deskriptif analisis, yaitu peneliti melukiskan fakta dan data yang didapat dari penelitian sebagaimana adanya (Hadari, 2005). Penggunaan metode deskriptif kualitatif ini bertujuan untuk memecahan masalah yang diselidiki dengan menggambarkan dan mengidentifikasikan faktor-faktor penghambat keterwakilan caleg perempuan pada pemilu legislatif tahun 2014 di Dapil III Kecamatan Boawae Kabupaten Nagekeo berdasarkan fakta-fakta atau data yang tampak atau sebagaimana adanya. Informan penelitian ini mencakup caleg perempuan (4 orang terdiri dari Regina Klara Dopo dari Partai Golkar caleg nomor urut 3; Maria Theresia Ugha dari PKB caleg nomor urut 5; Eutasia Djati caleg dari Partai Gerindra dengan No urut 6; dan Maria Ule, caleg dari PKPI dengan no. urut 3), pemilih perempuan (2 orang), pengurus Parpol (4 orang), pemilih/masyarakat (5 orang) dan tokoh masyarakat, tokoh agama, dan tokoh adat (3 orang).

\section{Pencalonan Perempuan sebagai Anggota Legislatif}

Untuk memberikan gambaran awal bagaimana kondisi keterwakilan perempuan di Dapil III Kabupaten Nagekeo, berikut penulis paparkan data-data susunan caleg perempuan di tiap partai. Sebagaimana dapat dilihat di tabel 2, sebagian besar perempuan ada di nomor urut bawah, dan tidak ada caleg yang lolos menjadi wakil rakyat. Kondisi penempatan caleg perempuan di nomor bawah ini merata di semua partai politik, kecuali Hanura, di Dapil III Kabupaten Nagekeo. Hal ini tentu menjelaskan bagaimana partai politik memandang urgensitas caleg perempuan didalam pencalonan serta bagaimana caleg perempuan sendiri melihat diri mereka di pemilu. Sebagaimana di tabel 2, kita dapat melihat bahwa partai politik semua memiliki caleg perempuan didalam daftar kandidatnya. Jumlah caleg perempuan di masing-masing partai ada 2, yang mengindikasikan jumlah minimalis pemenuhan syarat kuota. Tidak ada satupun partai politik yang melampau syarat minimal kuota 30 persen dalam 
pencalonan. Asumsi bahwa caleg perempuan hanya digunakan untuk memenuhi syarat administrative sepertinya terkonfirmasi.

Tabel 2 Penempatan Nomor Urut Caleg Perempuan di Dapil III Kec. Boawae

\begin{tabular}{|c|c|c|c|}
\hline Nama Partai & Nama Calon Perempuan & $\begin{array}{l}\text { No } \\
\text { Urut }\end{array}$ & Ket \\
\hline \multirow{2}{*}{ NASDEM } & Fransiska Awi Tai & 3 & Tidak lolos \\
\hline & Blandina Wula, SP & 5 & Tidak lolos \\
\hline \multirow[t]{2}{*}{$P K B$} & Maria Gaudalupe Bali & 3 & Tidak lolos \\
\hline & Maria Theresia Ugha & 5 & Tidak lolos \\
\hline \multirow[t]{2}{*}{$P K S$} & Maria H. Bai Nio & 3 & Tidak lolos \\
\hline & Marselina Welu Azi & 5 & Tidak lolos \\
\hline \multirow[t]{2}{*}{$P D I P$} & Theresia Waso Ea & 3 & Tidak lolos \\
\hline & Rowina Musa & 6 & Tidak lolos \\
\hline \multirow[t]{2}{*}{ GOLKAR } & Regina Klara Dopo & 3 & Tidak lolos \\
\hline & Maria Goreti Wae & 5 & Tidak lolos \\
\hline \multirow[t]{2}{*}{ GERINDRA } & Bernadetha Balak & 3 & Tidak lolos \\
\hline & Eustasia Djati & 6 & Tidak lolos \\
\hline \multirow[t]{2}{*}{ DEMOKRAT } & Kristina Daso & 3 & Tidak lolos \\
\hline & Maria Goreti Mi & 6 & Tidak lolos \\
\hline \multirow[t]{2}{*}{$P A \mathcal{N}$} & Anna Marllinda M.B S.Sos & 3 & Tidak lolos \\
\hline & Adelfina Magi Talo & 6 & Tidak lolos \\
\hline \multirow[t]{2}{*}{ HANURA } & Martina Ngengo & 1 & Tidak lolos \\
\hline & Dra. Kornelia Taso & 4 & Tidak lolos \\
\hline \multirow[t]{2}{*}{ PКPI } & Maria Ule & 2 & Tidak lolos \\
\hline & Bonafantiana Guyu & 4 & Tidak lolos \\
\hline
\end{tabular}

Sumber : KPUD Nagekeo

Lalu, bagaimana secara keseluruhan perolehan suara para caleg perempuan di dalam Pemilu Legislatif 2014? Berdasarkan data yang diperoleh dari KPUD Nagekeo, sebetulnya ada 1 caleg yang potensial memenangkan kursi. Akan tetapi, dalam rekapitulasi akhir, jumlah akumulasi suara masih belum mencukupi. Tabel berikut data lebih detil tentang perolehan suara masing-masing informan, sebagaimana di tabel 3 . Sebagaimana dapat kita lihat didalam tabel, sebetulnya dari 20 caleg perempuan, terdapat 2 nama yang berhasil memperoleh lebih dari 500 suara. Di samping itu, potensi lain, ada 4 calon yang berhasil meraih lebih dari 100 suara. Sebetulnya ini merupakan potensi dan menggambarkan pengakuan warga terhadap para caleg perempuan. Akan tetapi, dukungan structural yang diperoleh para caleg perempuan ini masih jauh dari harapan sehingga meskipun mereka memiliki potensi, mereka masih belum berhasil memenangkan kursi didalam Pemilu. Hasilnya, tidak satupun dari caleg-caleg ini yang berhasil terpilih duduk di kursi legislatif kabupaten. 
Tabel 3. Rekapitulasi Perolehan Suara Caleg Perempuan Dapil III Kabupaten Nagekeo

\begin{tabular}{|c|c|c|c|c|}
\hline Nama Partai & Nama Calon Perempuan & $\begin{array}{l}\text { No } \\
\text { Urut }\end{array}$ & $\begin{array}{c}\text { Jumlah } \\
\text { Suara }\end{array}$ & Ket \\
\hline \multirow[t]{2}{*}{ NASDEM } & Fransiska Awi Tai & 3 & 34 & Tidak lolos \\
\hline & Blandina Wula, SP & 5 & 16 & Tidak lolos \\
\hline \multirow[t]{2}{*}{$P K B$} & Maria Gaudalupe Bali & 3 & 6 & Tidak lolos \\
\hline & Maria Theresia Ugha & 5 & 12 & Tidak lolos \\
\hline \multirow[t]{2}{*}{$P K S$} & Maria H. Bai Nio & 3 & 62 & Tidak lolos \\
\hline & Marselina Welu Azi & 5 & 13 & Tidak lolos \\
\hline \multirow[t]{2}{*}{$P D I P$} & Theresia Waso Ea & 3 & 809 & Tidak lolos \\
\hline & Rowina Musa & 6 & 127 & Tidak lolos \\
\hline \multirow[t]{2}{*}{ GOLKAR } & Regina Klara Dopo & 3 & 52 & Tidak lolos \\
\hline & Maria Goreti Wae & 5 & 398 & Tidak lolos \\
\hline \multirow[t]{2}{*}{ GERINDRA } & Bernadetha Balak & 3 & 12 & Tidak lolos \\
\hline & Eustasia Djati & 6 & 20 & Tidak lolos \\
\hline \multirow[t]{2}{*}{ DEMOKRAT } & Kristina Daso & 3 & 104 & Tidak lolos \\
\hline & Maria Goreti Mi & 6 & 18 & Tidak lolos \\
\hline \multirow[t]{2}{*}{$P A \mathcal{N}$} & Anna Marllinda M.B S.Sos & 3 & 706 & Tidak lolos \\
\hline & Adelfina Magi Talo & 6 & 3 & Tidak lolos \\
\hline \multirow[t]{2}{*}{ HANURA } & Martina Ngengo & 1 & 29 & Tidak lolos \\
\hline & Dra. Kornelia Taso & 4 & 357 & Tidak lolos \\
\hline \multirow[t]{2}{*}{ PKPI } & Maria Ule & 2 & 88 & Tidak lolos \\
\hline & Bonafantiana Guyu & 4 & 8 & Tidak lolos \\
\hline
\end{tabular}

Bagian berikut mendiskusikan lebih dalam hambatan-hambatan yang dihadapi para caleg perempuan untuk dapat menjadi wakil di legislatif.

\section{Hambatan Politik Keterwakilan Perempuan}

Hambatan politik keterwakilan perempuan pertama-tama dikaitkan dengan implementasi aturan keterwakilan 30 persen, baik dalam kepengurusan partai politik dan penempatan daftar urut caleg perempuan. Kebijakan kuota 30 persen yang termaktub dalam Undang-undang Pemilu No. 12 Pasal 65 Tahun 2003 mewajibkan partai merekrut perempuan untuk ikut serta dalam pencalonan sebagai caleg anggota dewan. Hal demikian merupakan satu syarat partai bisa diikutsertakan dalam pertarungan pemilu legislatif.

Berdasarkan hasil penelitian ditemukan bahwa keterwakilan perempuan dinilai sudah memenuhi aturan kuota 30\% dalam kepengurusan partai politik dan perekrutan caleg perempuan oleh partai politik di Dapil III Kecamatan Boawae dan partai politik berusaha untuk menempatkan caleg perempuan pada nomor urut muda/nomor urut jadi setelah berunding secara internal partai. Penempatan nomor urut lebih sering ditempatkan pada nomor urut "sepatu". Berdasarkan informasi dari para caleg perempuan yang diwawancarai, caleg-caleg perempuan di Dapil III hanya ada 1 orang yang ditempatkan di nomor urut 1, tetapi juga tidak lolos. Paling atas diberikan nomor 
urut 3, lainnya hanya ditempatkan di nomor urut sepatu. Bahkan ada yang telah berjuang menjadi caleg sebanyak 3 kali pemilu namun belum berhasil lolos sebagai wakil rakyat. Mereka ini masuk partai 1 tahun sebelum Pemilu sehingga layak diduga jika keberadaan mereka ditujukan agar partai politik peserta pemilu memenuhi amanat undang-undang pemilu agar tidak mengalami diskualifikasi dalam pemilu.Partai tidak mempertimbangkan peningkatan kapasitas caleg perempuan sehingag mereka layak didukung dalam kompetisi politik.

Tentu saja, para pengurus partai berkilah bahwa mereka sudah emmenuhi prosedur Undang-undang. Partai hanya melihat bahwa perekrutan perempuan di legislatif itu dalam kepengurusan partainya dan pencalegan adalah untuk keikutsertaan partai dalam pemilu. Kedua, pemberian nomor urut bagi setiap caleg dilihat sebagai urusan internal internal elit partai. Sementara itu, posisi sebagai pengurus hanya mengesahkan saja.

Para pemilih sendiri mengaku tidak memilih caleg perempuan bukan karena merasa para caleg ini tidak pantas dipilih. Seorang informan menjelaskan, "(kebanyakan) mereka (warga) tidak terlalu paham apa yang disebut dengan keterwakilan perempuan $30 \%$ dikarenakan mereka baru mendengar soal aturan yang mengharuskan adanya wakil perempuan di kursi DPR. Informasi tersebut diketahui dari televisi. Pada dasarnya mereka senang dengan adanya undang-undang yang mengatur soal keterwakilan perempuan di kursi DPR, karena menurut mereka paling tidak suara perempuan bisa didengarkan. Tapi berkaitan dengan isi undang-undang tersebut mereka kurang memahaminya."

Namun demikian, masyarakat pada dasarnya menyambut baik regulasi tersebut. Tokoh masyarakat dan tokoh agama yang diwawancara menjelaskan, "berbicara mengenai undang-undang yang mengatur bahwa harus adanya keterwakilan 30\% bagi perempuan di kursi DPR saya salah satu orang yang sangat menyetujui, kenapa? Karena bicara soal perempuan yang bisa menjawabinya hanya perempuan sendiri, karena mereka mengerti kebutuhan mereka. Tuntutan suara perempuan harus didengarkan telah dijawab oleh pemerintah dengan menetapkan undang-undang untuk keterwakilan perempuan. Hal ini berarti paling tidak aspirasi perempuan bisa terjawab lewat pengambilan keputusan di DPR. Oleh karenanya partai politik jangan hanya merekrut perempuan demi kepentingan pemenuhan kuota saja tetap harus diimplementasikan." Namun dukungan ini masih belum berarti karena partai tidak memberikan respon yang memadai untuk mendukung keterwakilan perempuan.

\section{Hambatan Sosial dan Ekonomi Pencalonan}

Lemahnya sumber-sumber keuangan baik dari parpol maupun dukungan keluarga bagi caleg perempuan dalam aktifitas penggalangan massa seperti biaya sosialisasi, biaya kampanye dan atribut kampanye (biaya stiker, biaya baliho), beban ganda perempuan serta kurang adanya caleg perempuan yang dijadikan figur merupakan 
kendala yang menghambat keterwakilan perempuan di lembaga legislatif Kabupaten Nagekeo.

Hambatan sosial ekonomi ini pertama terkait dengan lemahnya sumber keuangan dalam aktivitas penggalangan masa serta atribut kampanye. Dari hasil wawancara langsung bersama keempat informan caleg perempuan, ditemukan bahwa sumbersumber keuangan yang kurang memadai baik dari parpol maupun dukungan keluarga dalam aktifitas penggalangan massa seperti biaya sosialisasi, biaya kampanye dan atribut kampanye (biaya stiker, biaya baliho), menjadi satu hal yang menyebabkan caleg perempuan tidak terpilih.

Para caleg perempuan mengakui bahwa uang mempunyai peranan penting dalam meloloskan mereka sebagai wakil rakyat di legislatif. Para caleg perempuan di Dapil III mengakui bahwa kendala keuangan sangat mempengaruhi aktivitas politik mereka. Informan mengatakan bahwa, "Dari segi finansial kurang menunjang dalam aktivitas politiknya seperti kurangnya dana untuk membuat stiker dan atribut lainnya, serta minimnya biaya transportasi untuk tim yang menjaring suara pemilih. Akan tetapi beginilah yang terjadi, saya maju dengan dana yang pas-pasan" (wawancara Ibu Klara Dopo, 19 januari 2017).

Informan lain mengatakan bahwa, "faktor uang untuk menang bukan rahasia lagi, inilah kenyataan politik. Serangan fajar tidak bisa disembunyikan lagi, ada uang berarti menang. Tanpa uang semuanya tidak bisa dijalankan. Tim sukses saja diminta untuk turun mencari suara harus diberi uang jalan saat bekerja. Faktor inilah yang menyebabkan kekalahan saya dalam pemilihan." Hal sama juga diakui oleh caleg tidak terpilih dari PKB dan Partai Gerindra bahwa mereka mengalami hal yang sama yaitu dari segi finansial. Maju menjadi caleg tanpa persiapan modal yang banyak itulah yang menjadikan alasan mengapa caleg perempuan yang terjun ke kursi parlemen tidak ada satupun yang lolos. Partai sendiri sebetulnya tidak lepas tangan. Beberapa partai memberikan dukungan dalam kampanye. Akan tetapi, sumber daya dukungan partai bagi para caleg ini tidak memadai. Lemahnya sumber keuangan membuat ketidakberuntungan bagi caleg perempuan dan keterlibatan partai pengusung tidak sepenuhnya memberikan kontribusi kepada setiap caleg pada partainya. Sedangkan pada sisi yang lain ditemukan bahwa biaya yang dikeluarkan oleh setiap caleg dalam menyiapkan atribut, penggalangan massa dalam kampanye cukup banyak namun kemampuan finansial dari para caleg perempuan lemah.

\section{Hambatan Kultural}

Sedangkan untuk faktor-faktor budaya yang menghambat keterwakilan perempuan menjadi salah satu alasan mengapa perempuan tidak terpilih: Pertama, ini terkait dengan labelisasi dan marginalisasi. Dari hasil penelitian ditemukan bahwa label stereotype yang ditanamkan kepada kaum perempuan turut mempengaruhi citra baku yang melekat pada peran, fungsi dan tanggung jawab yang membedakan antara laki-laki dan 
perempuan baik dalam keluarga maupun masyarakat. Cara berpikir stereotype tentang peran gender ini sangat mendalam merasuki mayoritas masyarakat. Para tokoh masyarakat mempunyai persepsi yang sama terhadap perempuan, yang diungkapkan dalam bahasa lokal yaitu sea mai (datang atau dibelis dari luar)" pu'u nebu-nebu jeka leza di vine gae kena ta beo dhe pedhe rubha, beo ko apa hoga, pedhe rubha jaga ana (dari dulu-dulu sampai sekarang tugas perempuan itu cuma di dapur dan menjaga anak dan pekerjaan rumah lainnya karena perempuan sudah dibelis atau dibeli).

Perempuan sebagai masyarakat kelas kedua ditetapkan oleh nenek moyang tidak bisa dipungkiri karena sudah menjadi budaya yang tidak bisa diubah lagi. Contoh kecil bila si perempuan bekerja di kantor siapa yang mengurus anak dan memaksakan nantinya. Ini bisa menimbulkan konflik dalam rumah tangga. Boleh berbicara soal gender tapi sulit untuk membalikan fakta budaya yang sudah mengakar (wawancara Henrikus Mite, 10 Januari 2017).

Kuatnya pelabelan negatif pada caleg perempuan akibat kuatnya budaya patriarki merupakan faktor budaya yang menjadi kendala terwakilnya perempuan di lembaga legislatif Kabupaten Nagekeo. Situasi ini dibenarkan oleh para caleg perempuan tidak terpilih dalam Pemilu Tahun 2014 bahwa budaya Nagekeo cukup sulit untuk dipengaruhi, sangat kental sekali budaya patriarki yang lebih mengagungkan laki-laki dan menempatkan perempuan pada posisi nomor dua, apalagi kalau perempuan tersebut telah dibelis saat menikah harus taat pada aturan adat. Akibat adanya budaya suda sea mai (pendatang akibat dibelis) masyarakat yang kental budaya menyatakan sikap tidak memilih perempuan yang telah dibelis (wawancara Maria Ule, 19 januari 2017). Dengan demikian pelabelan negatif kepada perempuan merupakan hal yang sudah menjadi bagian dalam kehidupan masyarakat Nagekeo pada umumnya (wawancara Maria Ugha, 24 januari 2017), yaitu adat istiadat sangat kuat didominasi oleh kaum laki-laki dan menganggap perempuan cuma bisa mengurus didapur, sehingga dijadikan kelompok kelas kedua dalam hidup bermasyarakat (wawancara Eustasia Djati, 25 Januari 2017).

Pelabelan strereotype dan marginalisasi yang diberikan kepada perempuan yang ada di Nagekeo sangat mempengaruhi nilai jual perempuan untuk menjadi seorang caleg yang berimbas pada ketidakterwakilnya perempuan di lembaga legislatif Kabupaten Nagekeo. Situasi dan kondisi terkait faktor kultur dibenarkan pula oleh pemilih yang sangat kuat memegang tradisi Nagekeo, yaitu penilaian masyarakat Nagekeo sudah pas untuk perempuan, hal yang sangat fatal bila seorang laki-laki dipimpin oleh seorang perempuan, apa laki-laki yang disebut sebagai mosalaki (orang terpandang) harus mendengar apa yang disampaikan oleh perempuan. "Budaya kita tidak seperti itu, budaya kita sudah dibekali oleh nenek moyang bahwa perempuan sebagai penunjang apa yang dikerjakan laki-laki", demikian seorang informan menjelaskan (wawancara Thomas Lowa, 18 Januari 2017). Secara hukum adat orang menilai vine gae kena ngaza ne'e raza re hoga mae moku ghi ne'e ana haki, hoga bhoda uru ato ka inu mena dapu (perempuan itu kalau 
ada duduk omong adat dorang tidak boleh duduk bersama dengan laki-laki, mereka harus siap makan, minum di dapur (wawancara Henrikus Mite, 10 Januari 2017).

Seorang informan laki-laki menjelaskan, "dengan demikian dalam hal memilih, para pemilih laki-laki merasa perlu untuk melihat latar belakang setiap caleg. Itu yang jadi alasan kenapa pada waktu pencoblosan laki-laki memilih caleg laki-laki, karena mereka lebih mampu dalam mengambil keputusan. Kalau saya memilih caleg perempuan saya masih ragu-ragu karena mereka sanggup atau tidak untuk mengambil keputusan. Lagian budaya kita sangat mengutamakan posisi laki-laki karena lebih pantas untuk menjadi pemimpin” (wawancara Krispinus Sipo, 23 Februari 2017).

Gambaran stereotype dan marginalisasi berdampak pada kesempatan perempuan untuk memperjuangkan hak-haknya menjadi sangat kecil, meskipun secara kuantitatif jumlah penduduk perempuan di Nagekeo lebih banyak dibanding laki-laki, tetapi kenyataannya tidak ada jaminan bagi hak-hak mereka. Pemahaman inilah yang mengakar kuat dalam tradisi masyarakat kita sehingga peran perempuan semakin dijauhkan dalam ranah politik.

Labelisasi ini sangat terkait dengan konteks masyarakat Indonesia, lebih khususnya di Kabupaten Negakeo, yang dikenal sebagai masyarakat yang kuat akan budaya patriarki, dimana penempatan posisi perempuan selalu berada di bawah laki-laki. Faktor utama caleg perempuan tidak terpilih bisa dilihat dari aspek budaya, karena masyarakat yang memegang teguh adat istiadat sering menilai perempuan itu pada kelas kedua. Apalagi kalau caleg perempuan itu dikatakan Se'a mai (pendatang), maka, akan sulit mendapat dukungan. Seorang informan caleg perempuan menjelaskan, "Susah kita hidup di budaya yang dominannya kaum lelaki, kalau bilang mampu ya saya mampu sekali. Saya kan pendatang dari luar ikut suami di sini, wajar saja lah orang tidak memilih saya yang latar belakang saya adalah pendatang. Ini yang membuat saya tidak terpilih. Penilaian pemilih terhadap perempuan yang bisa cuma di dapur itulah yang ada dibenaknya" (wawancara Eustasia Djati, 25 januari 2019). Memiliki latar belakang sebagai seorang pendatang (se'a mai) dan dicalonkan sebagai seorang caleg anggota legislatif sangat mempengarui tidak terpilihnya perempuan, itulah pengakuan dari para caleg tidak terpilih. Budaya yang kental akan kehadiran perempuan sebagai penunjang pekerjaan kaum laki-laki, bukan sebagai penentu dalam mengambil sebuah keputusan. Situasi ini dibenarkan oleh tokoh adat bahwa kekuatan budaya Nagekeo, budaya patriarki mengharuskan wanita untuk urusan di dapur, wanita dibelis datang ke rumah laki-laki dengan tujuan membantu pasangannya untuk menunjang pekerjaan keluarga laki-laki, dari turun-temurun diwariskan nilai ini. Akan ada masa dimana adanya aturan yang mengharuskan perempuan sebagai caleg itu wajar saja, kita jalani saja dengan perkembangan zaman suatu saat perempuan akan berperan penting dalam kehidupan perpolitikan (wawancara Ignas Mema, 29 Februari 2017).

Informan laki-laki yang lain menyatakan, "Saya menganggap bahwa perempuan maju menjadi caleg sama dengan membangkang dari aspek budaya yang bersepakat 
bahwa perempuan itu mengurus di dapur, laki-laki mencari nafkah, kodrat tidak bisa kita abaikan, negara mengakui persamaan gender tapi kita susah, masa seorang perempuan harus duduk didepan, lalu siapa yang harus mengurus dapur? Saya tidak bisa memilih perempuan karena takdir ini. Perempuan tidak bisa mengambil keputusan, rata-rata kami di desa ini susah memilih perempuan mungkin ada yang pilih karena faktor keluarga."

Berdasarkan analisa hasil penelitian baik hasil wawancara dengan tokoh adat, tokoh masyarakat, dan agama, dan pemilih ditemukan bahwa kekuatan budaya tidak bisa dibantah lagi, terbukti bahwa perempuan diberikan belis untuk datang ke rumah laki-laki untuk membantu setiap pekerjaan yang dikerjakan oleh laki-laki. Pemilih perempuan sebenarnya mendukung kaumnya, akan tetapi memiliki ketergantungan terhadap lelaki sebagai suami sangat tinggi, sehingga setiap keputusan didiskusikan bersama, termasuk keputusan untuk memilih caleg ditentukan oleh kepala rumah tangga, yakni suami.

\section{Hambatan dari dalam Diri Perempuan}

Faktor penghambat yang berasal dari dalam diri caleg perempuan berupa pertama mencakup kurangnya rasa percaya diri yang diakibatkan terlalu banyaknya beban yang ditanggung perempuan. Pengalaman dalam berpolitik yamg minim, tidak pernah melakukan kampanye langsung untuk bertemu masyarakat, dan tidak memiliki hasrat yang kuat untuk bersaing, serta memiliki beban ganda yakni harus berperan sebagai ibu rumah tangga sekaligus berperan sebagai wanita karier, membuat perempuan tidak yakin untuk maju di Pileg.

Akibatnya, banyak caleg perempuan yang kurang maksimal menunjukkan eksistensinya sebagai caleg. Hal ini berdampak pada pemilih yang kurang mengenal caleg perempuan (baik dari segi kompetensi dan sepak terjang politiknya) yang bertarung dalam pileg 2014 di Dapil III Kabupaten Nagekeo. Hal ini dikarenakan semua urusan politik terkait pileg baik yang terkait dengan sosialisasi calon, pembagian atribut kampanye maupun pelaksanaan kampanyenya dipercayakan pada tim sukses untuk mengurusnya. Tidak banyak caleg perempuan yang mau terjun langsung ke akar rumput/masyarakat pemilih untuk memperkenalkan diri untuk menjaring suara pemilih.

Kedua, hasrat untuk bersaing dengan kaum laki-laki di antara kaum perempuan rendah. Tidak semua perempuan memiliki hasrat untuk bersaing di legislatif. Dalam mengikuti pemilihan umum untuk menjadi caleg pun itu dipaksakan atau diminta oleh partai, bisa jadi lebih karena keluarga untuk memenuhi kuota. Kemauan untuk dicalonkan sebagai caleg tidak datang dari diri caleg perempuan tersebut, tetapi lebih karena dorongan dari luar diri, yaitu terpaksa menerima tawaran/bujukan dari partai politik agar dapat menjadi peserta pemilu.

Hasilnya, tidak sedikit yang sekedar coba-coba. Sebagaimana salah informan caleg perempuan menjelaskan, "Bergelut di partai baru mulai satu tahun, sebenarnya belum saaatnya saya ikut calon. Saya ingin belajar lebih banyak lagi di Partai Gerindra. Akan tetapi mau bagaimana lagi kalau dari partai meminta, terpaksa coba-coba saja." 
Tentu saja, keputusan untuk coba-coba jadi tidak terukur. Hal ini mengindikasi hasrat perempuan untuk bersaing dalam pemilu rendah, sehingga tidak mengherankan jika mereka tidak terpilih.

Dari penjelasan di atas, kita bisa melihat bahwa berbicara tentang keterwakilan perempuan memang sudah menjadi bahan kajian yang jamak. Akan tetapi, selalu tidak ada perubahan yang berarti. Pengalaman di Dapil III Kabupaten Nagekeo menjelaskan kepada kita bahwa persoalan politik, sosial ekonomi dan budaya serta hambatan dari dalam diri perempuan sendiri merupakan penjelas susahnya perempuan memperoleh kursi didalam lembaga legislative, menyebabkan rendahnya keterwakilan perempuan.

\section{Penutup}

Berdasarkan diskusi di atas, kita dapat melihat bahwa hambatan-hambatan yang menjadi faktor penjelas rendahnya keterwakilan perempuan di Kabupaten Nagekeo, NTT sangat terkait erat dengan kendala politik. Partai lebih memprioritaskan caleg lakilaki dibandingkan caleg perempuan, sehingga terkesan keberadaan caleg perempuan hanya untuk memenuhi aturan 30\% keterwakilan perempuan sebagai syarat bagi pencalonan anggota legislatif oleh partai politik peserta pemilu. Kedua, hal ini terkait dengan kendala sosial ekonomi. Tidak terpilihnya caleg perempuan dipengaruhi oleh kurangnya sumber-sumber keuangan baik dari parpol maupun dukungan keluarga dalam aktifitas penggalangan massa seperti biaya sosialisasi, biaya kampanye dan atribut kampanye (biaya stiker dan biaya baliho). Ketiga terdapat hambatan Budaya.Faktor utama penyebab tidak terpilihnya caleg perempuan dipengaruhi oleh budaya patriarki. Bagi masyarakat Nagekeo yang secara khusus di Dapil III Kecamatan Boawae, keberadaan perempuan dipandang sebagai kelas kedua karena perempuan itu mengikuti suami (tradisi belis) yang hanya bisa bekerja di dapur, mengurus suami serta anak-anak, dan apabila melanggar dianggap sebagai perempuan yang sedang membangkang terhadap tradisi budaya Nagekeo. Keempat, penting juga melihat faktor dari dalam perempuan sendiri. Dalam berkampanye, para caleg perempuan tidak memanfaatkan kelompok-kelompok organisasi kemasyarakatan yang ada di masyarakat. Caleg perempuan mempercayai tim sukses, sehingga tidak turun langsung ke masyarakat untuk bersosialisasi memperkenalkan diri, dan tidak terlibat dalam kampanye disebabkan kurang percaya diri akibat dari kurangnya pengalaman dan pendidikan politik dari partai pengusung. Fungsi pendidikan politik (diklat politik) dari partai politik tidak berjalan baik. Jadi wajarlah masyarakat tidak memilih mereka. Dengan demikian, jelas bahwa ketidakterwakilan perempuan melibatkan faktor penyebab yang kompleks.

\section{Ucapan Terima Kasih}

Penulis mengucapkan terimakasih kepada semua pihak yang telah berkontribusi dalam penelitian dan penulisana artikel ini. 


\section{Pendanaan}

Penulis tidak menerima bantuan pembiayaan untuk penelitian, kepenulisan (authorship), dan publikasi dari pihak manapun.

\section{Daftar Pustaka}

Ananta, A., Arifin, E. N., \& Suryadinata, L. (2004). Indonesian Electoral Behaviour: A Statistical Perspective. Institute of Southeast Asian Studies.

Budiardjo, M. (2003). Dasar-Dasar Ilmu Politik. Jakarta: Gramedia Pustaka Utama.

Dahlerup, D. (2002). Menggunakan Kuota untuk Meningkatkan Representasi Politik Perempuan dalam Perempuan di Parlemen: Bukan Sekedar Jumlah. IDEA.

Fakih, M. (2008). Analisis Gender dan Transformasi Sosial. Insist Press.

Fatmariza, F. (2005). Representasi Perempuan dalam Lembaga Legislatif di Sumatra Barat Pasca Quota 30\%. Jurnal Demokrasi, 4(1).

Gaffar, A. (2000). Politik Indonesia, Transisi Menuju Demokrasi. Kedua, Pustaka Pelajar, Yogyakarta.

Haboddin, M., \& Rahman, F. (2013). Gurita Korupsi Pemerintah Daerah. Kaukaba Dipantara.

Hadari, N. (2005). Metode Penelitian Bidang Sosial. Yogyakarta: Gadjah Mada University Press.

Haryanto. (1984). Partai Politik: Suatu Tinjauan Umum. Jogjakarta: Liberty.

Hasyim, S. (2010). Perempuan dalam Fiqih Politik. Bandung: Mizan.

Kristoforus Rangga, W. (2014). Strategi Kampanye Calon Anggota Legislatif Perempuan dalam pemilu Legislatif 2014 di Dapil II Kecamatan Keo tengah Kabupaten Nagekeo.

Lovenduski, J. (2008). Politik Berparas Perempuan. Kanisius.

Mulia, M., \& Farida, A. (2005). Perempuan dan politik. Gramedia Pustaka Utama.

Murniati, A. N. P. (2004). Getar Gender. Indonesiatera.

Naqiyah, N. (2005). Otonomi Perempuan. Malang: Bayumedia Publishing.

Prihatmoko, J. J. (2008). Mendemokratiskan PEMILU. Yogyakarta: Pustaka Pelajar.

Rahardjo, S. (2006). Ilmu Hukum. VI, Bandung: Citra Aditya Bakti.

Samego, I. (2000). Book Review Ekonomi Politik. Jakarta: Pasca Sarjana Ilmu Politik, Universitas Nasional.

Samego, I. (2017). Politisasi Intelijen di Era Soekarno, 1945-1965. In I. N. Bhakti, D. M. Mengko, \& S. N. Siregar (Eds.), Intelijen dan Politik Era Soekarno. Jakarta: LIPI Press.

Sastriyani, S. H. (2009). Gender and Politics. Yogyakarta: Tiara Wacana.

Shvedova, N. (1999). Kendala-Kendala Terhadap Partisipasi Perempuan di Parlemen dalam Perempuan di Parlemen, Bukan Sekedar Jumlah, Bukan Sekedar Hiasan. Jakarta: Yayasan Jurnal Perempuan.

Sridanti. (2010). Furnal Perempuan 45. Jakarta: Yayasan Jurnal Perempuan.

Sugiyono. (2011). Statistika untuk Penelitian. Bandung: Alfabeta.

Utami, S. W. H. (2001). Perempuan Dalam Pusaran Demokrasi, Dari Pintu Otonomi ke Pemberdayaan. Bantul: IP4 Lappera Indonesia.

Wijaksana, W. (2004). Politik dan Keterwakilan Perempuan. Jurnal Perempuan untuk Pencerahan dan Kesetaraan (Vol. 34). Jakarta.

Wijaya, H. (2001). Perempuan dalam Pusaran Demokrasi. Bantul: IP-4 Lapera. 


\section{Catatan}

${ }^{1}$ Politik mewujudkan diri dalam diskusi dan perbincangan dimana "ruang antara" (antarmanusia terbuka dan sebuah dunia bersama terbentuk). Dalam politik, dunia bersama dibangun atas dasar komunikasi. Keputusan politis tidak semata diambil atas dasar suara terbanyak, tapi harus lahir dari sebuah proses diskursus. Diskursus menciptakan dunia bersama yang memungkinkan sebuah hidup bersama.

${ }^{2}$ Dalam proses demokratisasi, persoalan partisipasi politik perempuan menjadi prasyarat mutlak bagi terwujudnya demokrasi yang lebih bermakna di Indonesia. Bahkan, tuntutan representasi perempuan bukan semata soal demokratisasi, teteapi juga untuk menciptakan pemerintahan yang lebih transparan, egaliter dan akuntabel. Demokrasi yang bermakna adalah demokrasi yang memperjuangkan kepentingan kelompok tertindas seperti perempuan. Bdk. Sri Wahyuni dan Hedwigis Esti R, Pandangan Publik tentang Keputusan Perempuan dalam Kancah Politik Indonesiall dalam Siti Hariti Sastriyani, Gender and Politis, (Yogyakarta: Tiara Wacana, 2009), p. 201.

${ }^{3}$ Diolah dari data Komisi Pemilihan Umum (KPU) Kabupaten Nagekeo tentang data pemilih pada Pemilu 2014.

\section{Tentang Penulis}

Veronika Ina Assan Boro adalah Dosen Ilmu Pemerintahan di Universitas Katolik Widya Mandira Kupang.

Alexander Efraim Tade Kale adalah mahasiswa Ilmu Pemerintahan di Universitas Katolik Widya Mandira Kupang. 